\title{
REVIEWS
}

\section{Feminism and Youth Culture: From Jackie to Just Seventeen}

Angela McRobbie

Macmillan: London 1991, £9.99 Pbk

ISBN $033345264 \mathrm{X}$, £35.00 Hbk

ISBN 0333452631

\section{Schoolgirl Fictions}

Valerie Walkerdine.

Verso: London 1991, £10.95 Pbk ISBN 0860915174 , £32.95 Hbk ISBN $086091299 \mathrm{X}$

Unfortunately, the first thought that came to mind when looking at these two collections of feminist essays was-I seem to have read most of this stuff before ...

While these 'new' scholarly collections share an emphasis on the often neglected subject of workingclass female adolescence, both books, because they contain such a lot of reprinted material, at first sight do appear to be disappointingly 'retrospective'. For instance, both McRobbie and Walkerdine included material in these 1991 volumes which previously made a debut in the 1984 Macmillan collection Gender and Generation. ${ }^{1}$ However, the largely reprinted nature of these 'new' collections does not invalidate them or mean they are not useful.

Very little has been said about the role of girls in youth cultural groupings' commented Angela McRobbie and Jenny Garber in 1978. ${ }^{2}$ Thirteen years later Angela McRobbie has significantly contributed to changing this situation. This new book gathers together eight essays about the lived experience of girls in youth culture and popular culture. By presenting previously published work in this way McRobbie offers readers of Feminism and Youth Culture cultural analysis and careful ethnography in the context of the development of her own ideas.

Despite the fact that some of the empirical examples in this collection look a little dated, the writing is accessible and raises many theoretical questions about the behaviour of working-class girls that still require attention today. This is largely because McRobbie's writing, past and present, rarely offers a simple interpretation of why female experience had been marginalized by early subcultural theorists.

Essays like 'Settling Accounts with Subculture', included here but first published in 1980 were of seminal influence. ${ }^{3}$ This particular essay was written when McRobbie was at the Centre for Contemporary Cultural Studies at Birmingham University. Her writing from that period, as she indicates in the Introduction, was inspired by the moment when interdisciplinary perspectives were brought to bear on the study of 
culture, defined by Raymond Williams not as something saved for Sunday best, but as 'a whole way of life'. Here, McRobbie's work was significant because her emphasis on ordinary femininity made a serious contribution to the debate which located gender as something 'cultural' rather than 'natural'.

Indeed, McRobbie broke new ground when she suggested girls' position in youth subcultures like Teds and Mods had either been ignored or inappropriately described as one of passivity by male researchers. ${ }^{4}$ She went on to identify how in classic subcultural studies the street life of working-class boys had been overprivileged at the expense of discussion of family life, domestic labour and the structural position of gender ideologies.

Yet the essays in Feminism and Youth Culture do not go on, as some readers may anticipate, to look at how these issues affected analysis of female participation in more recent youth cultural groupings. For instance, this book doesn't consider the role of young women in more recent subcultures, from the New Romantics to Acid House. ${ }^{5}$ Instead, McRobbie moves on to write about teenagers and consumerism, an intellectual strategy which is extremely relevant since subculture doesn't mean what it did.

In the nineties - when authentic subcultural activity seems to change so quickly - youth style appears to have more in common with lifestyle marketing employed by advertising and the fashion industry, than with a 'counter-cultural' space outside of consumerism. (Nowadays many young people have been through more than one subcultural experience before they are out of their teens.) Although McRobbie doesn't come right out and state in this collection exactly why she moved away from straightforward discussion of subcultures to focus on other issues raised by youth consumerism, there are hints in the early essays that demonstrate the astute perception underlying her shift of emphasis.

In $1978 \mathrm{McRobbie}$ insisted that critics should not really get caught up in counting the presence or absence of girls in street gangs but instead should try and understand the way young women form their own subcultures, and how these are understood and accommodated by girls' magazines. ${ }^{6}$ This focus appears to have provided the impetus for much of McRobbie's subsequent work which is preoccupied with unravelling the contradictory aspect of the authentic and the manufactured nature of teenage culture as well as decoding the meaning of style.

By studying girls' magazines from Jackie to Just Seventeen - and the way teenage girls make sense of them, McRobbie takes seriously the function of fantasy. In 'Teenage Mothers: A New Social State', a new essay written for this collection, she also considers economic questions when she assesses well-documented ground about the consequence of the allure of motherhood for workingclass girls in the context of antischool subcultures. Yet it is McRobbie's analysis of the commodification of teenage daydreams by comics that continues to be controversial (if Martin Barker's recent criticisms in Comics, Power and Ideology (1989) are anything to go by). ${ }^{7}$ This approach to the discussion of fantasy, which may appear eclectic to those not familiar with cultural-studies methodology, is important not least because McRobbie begins to raise questions taken up by the theorists of the so-called postmodern age. ${ }^{8}$

Similar concerns about young women and their relationship to school and fantasy are also raised by Valerie Walkerdine in Schoolgirl Fictions, which includes twenty essays written between 1981 and 1989 . Walkerdine's methodology differs from McRobbie's, however, because as well as including autobiographical fragments and poetry Walkerd- 
ine privileges a psychoanalytic reading of popular culture forms (which she measures against empirical data and her own experience) to investigate gender as fiction.

Schoolgirl Fictions is separated into three sections. The first contains essays written between 1981 and 1985 and looks at unwitting bias embedded in pedagogic strategies (Walkerdine, 1989). This section commences with 'Sex, Power and Pedagogy', an essay which sets out to challenge the idea that pupils are powerless in the classroom. Walkerdine's investigation of the discourse of young boys considers how male pupils are easily able to 'resist the authority of female teachers (speech like 'Miss Baxter show your knickers off')' by utilizing patriarchal narratives about sexual objectification. It contrasts how female pupils are virtually silenced by the subjectivities constructed for them by pedagogic definitions and expectations.

These ideas are further developed in 'Science and the Female Mind', another essay in which Walkerdine identifies some of the gender fictions that abound in the classroom. She says these gender fictions place different expectations on boys and girls in relation to subjects like mathematics: 'in spite of obvious success girls' performance is constantly demonstrated to be different ... the idea that difference is in some way a deficiency, surfaces time after time.' Other essays on educational themes, which may be familiar to Feminist Review readers, go on to develop Walkerdine's analysis of power/knowledge in education which she says "cannot be understood historically outside considerations about gender'.

Sections two and three of Schoolgirl Fictions, written between 1984 and 1989 about popular culture and working-class childhood did not follow on easily from the earlier educational emphasis. Despite the fact the author had written new prefaces to bind material together the sequence was, at times, difficult to follow other than chronologically. On the whole, the inclusion of fragments of autobiography made the otherwise academic tone of the book, which addresses poststructuralist issues about subjectivity, much more readable. Sometimes I felt Walkerdine's inclusion of personal experience really fleshed out dry psychoanalytic observations and managed to inject vibrant colour to the monochromic specificity of empirical evidence. Other articles, about working-class lives, which were also autobiographical in focus, were perhaps too earnest about the past. They seemed to concentrate upon uncovering forgotten emotions rather than taking the opportunity to include specific historical detail.

To summarize the rest of the book: section two examined narratives about gender represented in popular culture. Essays like 'One Day My Prince Will Come', ${ }^{9}$ examined fictions about femininity available in teenage comics and still managed to offer a persuasive discussion about the influence romantic fantasies have upon teenage years, despite the fact that I had read a lot of this material before. (This point is also addressed by McRobbie.) Similarly 'Behind the Painted Smile' - an essay which is incidentally also reprinted in the Virago collection on photography (Spence and Hollands, 1991) - raised many questions about photographic fictions which obscure complicated emotions beneath the surfaces of smiling portraits. This was one of my favourite pieces as I felt it managed to get the balance right when discussing the relationship of the personal to the political.

'I felt in the old place, as in the new, that if I opened my mouth it would be to say the wrong things', Walkerdine comments in section three about feeling out of step with the cultural formations she encounters (a feeling this reviewer recognizes only too well). This final section contains Walkerdine's 'look back in 
anger' at working-class culture in the form of autobiographical pieces about the author's painful journey between the two worlds of then and now. While I identified with many of the complicated emotions involved in Walkerdine no longer feeling completely at home in either the clothes of the working-class schoolgirl or the middle-class academic, ${ }^{10}$ I think the generational gap showed in these retrospective articles. Walkerdine's emphasis on discourse theory and 'fictions of gender' to explain her experiences in the academy were persuasive but unable directly to address the financial hardships faced by contemporary workingclass students or part-time lecturers.

Today's Women's Studies students - including lesbian, workingclass and black women - hopefully have more space to speak about the alienation that comes from engaging with white/male/middle-class (or even feminist) epistemologies than Walkerdine may have had. For them, and lecturers without tenure, however, economic issues affecting education are far more biting than they were in the sixties and seventies. In the nineties, for instance, grant or part-time lecturing income doesn't adequately cover research time required and there are literally not enough books in poly libraries adequately to accommodate students who cannot afford to buy some of their own.

So despite my genuine respect for the feminist scholars and the positive elements of their books reviewed here, I find it necessary to separate text from context in order to discuss the material fully. Indeed, the appearance of two reprinted feminist collections at the same time did raise questions for me about the politics underlying the publishing of reissued material.

It may be true that Women's Studies lists are now being offered by academic publishers more than ever before and there is demand for material. But at a time when feminist research grants are being cut and autonomous feminist publishing is in decline, ${ }^{11}$ it is perhaps worrying that the live feminist scholarly reprint looks set to oust or supplement the trend for reprinting the novels of dead women. (A phenomenon pioneered by Virago ${ }^{12}$ and copied by British publishers including left houses.)

In the 1990s I suspect we will be reading or reviewing many feminist essays the second time around and at the right cover price this is no bad thing. But cover prices are high, and given that most academic publishers don't pay authors the sort of advances that would be needed to finance new research, I would call for feminists who do allow their work to be reprinted to think about where else it is available. For example, I have some of the articles in these two 'new' books in two other places, and feel disappointed, or dare I say it, short-changed by this.

Indeed, it is about time publishers were pressurized to reduce prices of books made up almost entirely of reissued material. I may be a cynic but I am not convinced that this recycling and reprinting provides a true indication of renewed interest in feminism. It seems likely that the live feminist scholarly reprint developed as a phenomenon not only because feminist thinkers are at last becoming recognized, but because it constitutes low-investment publishing. Obviously authors have their own reasons for authorizing the reissue of their work ${ }^{13}$ and so it would be inappropriate to say that reprints constitute 'exploitation' or simply another publishing 'scam'. Yet in the rush to reprint the past, both publishers and authors should take care to ensure that feminism doesn't look like it has run out of new ideas or fresh ways to express them.

\section{Lorraine Gamman}




\section{Notes}

1 This collection is out of print.

2 Quote from McRobbie (1979) which originally appeared in Hall (1978).

3 This article originally appeared in Screen Education (1980) No. 39.

4 Cohen (1972); Willis (1977); Hebdidge (1979)

5 For those interested there is discussion about this in contemporary subculture: McRobbie (1989). There is also some excellent writing on women and punk in Evans and Thornton (1990). Brake (1985) offers a good summary of early writing on girls and subculture.

6 'Girls and Subcultures' essay in McRobbie (1991: 11).

7 Barker (1989). These criticisms seem to be adapted from an earlier article: Martin Barker, (1986) 'Methods For Cultural Studies Students' in Punter D.

8 Angela McRobbie has contributed journalism to debates about postmodernism including an article in Lisa Appignanesi., editor, (1986) Postmodernism, ICA Document 4 published in association with Free Association Books.

9 First published in McRobbie and Nava (1984).

10 Similar impulses, that is achieving some social mobility but still finding certain doors closed, originally made sixties new wave playwrights - like Osborne. - angry in the first place. In Walkerdine's book, patriarchal, as well as class relations, incite her anger in terms of the way they create an impasse in some academic structures and epistemologies.

11 See publishing overview presented by Helen Birch.

12 I am personally not against the publishing of artistically or historically significant reprints. But I think the points made by Rebecca O'Rourke in 'Summer Reading' (Feminist Review, No. 2) that 'commercial publishers are cashing in on feminism', raised again by Ros Coward on p. 235 of Showalter (1986) are still relevant.

13 Williamson (1991) outlines the 'publish or perish' philosophy. Her article argues British higher education is following the American precedent whereby publishing is what is valued rather than teaching practice.

\section{References}

BARKER, Martin (1989) Comics, Power and Ideology Manchester: Manchester University Press.

BIRCH, Helen (1991) 'Bold Types in a Buyers Market', New Statesman 31 May.

BRAKE, Michael (1985) Comparative Youth Culture London: Routledge \& Kegan Paul.

COHEN, Stanley (1972) Folk Devils and Moral Panics: The Creation of the Mods and Rockers London: MacGibbon \& Kee.

EVANS, Caroline and THORNTON, Minna (1990) Women and Fashion: A New Look London: Quartet.

HALL, Stuart (1978) editor, Resistance Through Ritual London: Unwin Hyman. Reprinted 1989.

HEBDIGE, Dick (1979) Subculture: The Meaning of Style London: Methuen.

MCROBBIE, Angela (1979) 'Girls and Subcultures' in HALL (1978).

- (1989) editor, Zoot Suits and Second Hand Dresses Basingstoke: Macmillan.

- (1991) Feminism and Youth Culture Basingstoke: Macmillan.

MCROBBIE, Angela and NAVA, Mica (1984) editors, Gender and Generation Basingstoke: Macmillan.

PUNTER, D (1986) editor, Contemporary Cultural Studies London: Longman.

SHOWALTER, E. (1986) editor, The New Feminist Criticism London: Virago.

SPENCE, Jo and Patricia HOLLANDS, (1991) editors Family Snaps: The Meaning of Domestic Photography London: Virago.

WALKERDINE, Valerie (1989) Counting Girls Out London: Virago.

- (1991) Schoolgirl Fictions London: Macmillan.

WILLIAMSON, Judith (1991) 'Never Mind the Quality Think for Yourself' The Guardian 25 April.

WILLIS, Paul (1977) Learning to Labour Farnborough: Saxon House.

\section{From Abortion to Reproductive Freedom: Transforming A Movement}

Edited by Marlene Gerber Fried South End Press: Boston $1990 £ 8.95$ ISBN $089608387 \mathrm{XPbk}$
The Supreme Court ruling on Roe v. Wade in 1973 was as significant to American women as the passing of the 1967 Abortion Act was for women in Britain. It legalized abortion. Since 1973 some 25 million women have had legal abortions in the USA. The Roe ruling was based on the 